\title{
Self-Assessment of Engineering Learners' Perception of Usefulness of Pre-Writing Strategies
}

\author{
Ramya Devi Bommanaboina ${ }^{1}$ \& Rajakumar Guduru² \\ ${ }^{1 \& 2}$ School of Humanities, Social Sciences and Management, Indian Institute of Technology, \\ Bhubaneswar, India \\ Correspondence: Rajakumar Guduru, Indian Institute of Technology, Bhubaneswar, India. \\ Email: rajakumarguduru@iitbbs.ac.in
}

DOI: $10.53103 /$ cjlls.v1i3.18

\begin{abstract}
The engineering undergraduate students at premiere institutions give more importance to core subjects often neglecting the English language. Specifically, these students consider academic writing less important than other language skills such as speaking, reading, and listening. As a result, these students are at a big disadvantage in the industry and while applying for higher education. Hence, the present study has attempted to understand the students' perceptions of usefulness of prewriting strategies. For this purpose, 439 engineering undergraduate students (357-males and 82females) have been administered a self-assessment questionnaire of pre-writing strategies. The main research tools used in this study were a structured self-assessment questionnaire and informal interviews with the students. The quantitative data was analyzed through statistical procedures in SPSS-26 software. The analysis of the students' interviews was described. The findings showed that the majority of the engineering students have positive perception towards the usefulness of prewriting strategies. The results revealed that there was no significant difference between the male and female students' perceptions of usefulness of pre-writing strategies. The study recommends improving engineering students' pre-writing strategies and also proposes remedial teaching for fostering basic ESL writing requirements of students who come from disadvantaged backgrounds.
\end{abstract}

Keywords: Engineering Students, Self-Assessment, Pre-Writing Strategies, Students' Perception

\section{Introduction}

It is our experience of teaching the undergraduate engineering students at a premiere institute in India that has driven the need for this research. We have learnt that engineering students have to study all subjects in English language throughout the academic career. Of all the skills, writing becomes a fundamental skill for students which decides their academic success from submitting written assignments to writing final examinations. However, based on the academic backgrounds they come from, it is observed that most of the engineering students' writing is seen as average and below 
average.

In the global education context, academic writing is increasingly becoming important for science, technology, engineering and maths (STEM) students all over the world. A number of courses both online and offline are offered by various universities to help these students succeed in their academics. Engineering degree programmes require students to complete various academic assignments, internship programmes and other activities from time to time. If the students are not equipped with adequate academic writing skills, they may face real-word problems in the work place or in similar situations.

The entry level engineering students studying at the premiere engineering institutions in India, having come from different educational backgrounds, exhibit various learning styles and also seem to have personal preferences for learning English language skills. Apparently, these individual learning styles and preferences will affect their academic performance. Writing along with the speaking skills forms very much part of the academic language required for students' academic success. However, writing is one of the languages skills which students often consider it as difficult and complex to learn. In an academic context, besides mastering the knowledge of the hard skills, studying courses in engineering requires and emphasizes learning new skill sets such as communication skills, presentation skills, soft skills, and personality development skills. It implies that an engineering graduate should acquire a blend of technical as well as soft skills to become a highly skilled and knowledgeable graduates.

Engineering students are given admission into premiere institutions based on their rank in the JEE exam which is conducted at national level. These students come from different socio-economic, educational, linguistic and demographic backgrounds. Therefore, these students possess varied levels of proficiency in English language skills. For most of the learners the pressure for improving their writing skills is amplified because they have to do class assignments, write exams, do projects, draft emails, write job applications, and prepare resumes. However, it is observed that these engineering students seem to lack good understanding of writing skills. Firstly, these students think that writing is not important for them, and so they lack motivation and interest to improve writing skills. Secondly, they do not seem to be aware of that writing as a process through the pre-stage, while writing stage, and post writing stage. Next, these students do not have adequate support in improving their writing skills. Finally, students are not aware of the importance of pre-writing strategies which will help and improve their writing.

Hence, there is a felt need to understand engineering students' perceptions of usefulness of pre-writing strategies in actual improvement of their overall writing. To the knowledge of the researchers, there are very few studies specially on self-assessing engineering students' perceptions of usefulness of pre-writing strategies in the Indian context. Therefore, the study mainly aims at understanding engineering students' perceptions of usefulness of pre-writing strategies. This study will help teachers to 
understand students' pre-writing strategies and how their perceptions of pre-writing will help to achieve success in academic writing.

\section{Research Questions}

This study aimed to address the following research questions:

1. What are the ESL learners' perceptions of usefulness of pre-writing strategies?

2. Is there any significant difference between male and female students' perceptions of usefulness of pre-writing strategies?

3. What are the possible effects of self-assessment of students' perceptions of prewriting strategies?

\section{Objectives}

The objectives of the study are:

1. to know students' perceptions of the pre-writing strategies.

2. to understand students' motivation and interest for writing.

3. to know the effect of learners' self-assessment of pre-writing strategies on their writing.

4. to know the significant difference between the male and female students' perceptions of pre-writings strategies.

\section{Literature Review}

\section{Self-Assessment}

Self-assessment has emerged as an alternative procedure in the field of evaluation for addressing the inherent limitations of teacher assessment (Hargreaves, Earl, \& Schmidt, 2001). According to Boud (1995) and Bailey (1998), self-assessment is the technique by which students evaluate and give feedback on their own performance. Brown and Harris (2013) defined self-assessment in the K-16 context as a "descriptive and evaluative act carried out by the student concerning his or her own work and academic abilities" (p.368). Panadero et al. (2016) defined it as a "wide variety of mechanisms and techniques through which students describe (i.e., assess) and possibly assign merit or worth to (i.e., evaluate) the qualities of their own learning processes and products" (p. 804).

Boud \& Falchikov (1989) considered self-assessment as an important process in undergraduate education as it helps the learners to reflect on their own performances and monitor their own learning. The learners are more actively engaged in the educational process by taking greater responsibility for goal-setting and decision making about their own learning (Hughes, \& Mylonas, 2002). Brown and Hudson (1998) also stated that 
students 'greater autonomy in self-assessment can substantially increase their motivation to learn the language. According to Marhaeni \& Artini (2015) self-assessment as a tool of self-reflection will help the language students identify their mistakes and weaknesses in language use (linguistic) and the organization of spoken or written communication. According to Nedzinskaite, Švenčionienè, \& Zavistanavičienè (2006) self-assessment is considered as a new innovation in the testing process. The main focus of SA is not on what the students do not know but what they do. Self-assessment develops self-responsibility among students by providing autonomy over their own learning (Broad, 2006).

\section{Self-Assessment of Writing}

Many theoretical models support the inclusion of self-assessment in the assessment of writing. Self-assessment in writing helps the learners to evaluate and revise their own piece of composition. Writing, like all the other skills, is taught and practiced from the initial stages of language learning. It is always evaluated and assessed by the teacher. However, the learners usually have no idea of their place in writing skills and cannot evaluate themselves (Bjork, 1994, 1999). As a consequence, they fail to monitor their own learning process and solely depend on teachers' feedback. The study of Fahimi \& Rahimi (2015) made an attempt to provide opportunities for the learners in assessing their own written composition under the guidance of their teacher. Forty-one female teenage students in four classes in the intermediate level from a private institute in the city of Tehran, Iran participated in the study. The results suggested that self-assessment has helped students to evaluate the progress of their writing and the ability of writing as well. The study also revealed that it is highly essential to encourage students for adopting a more active and independent role in testing process. By doing so, the learners become more conscious of their errors they have made.

Another study carried out by Ross et al. (1999) revealed that self-evaluation had a much larger impact on the performance of poorer writers. It provides explicit feedback to the poorer writers on what they need to improve and what is more required to them. This feedback is more precise and accurate than the feedback that they usually receive from the teacher. A recent study conducted by Thongpai and Deerajviset (2017) discovered the significant effect of self-assessment on writing skills of Thai EFL students with different learning styles. The result indicated that the use of self-assessment was useful for most of students having different learning styles in revising their writing and knowing their writing strengths and weaknesses.

\section{Perceptions of Pre-writing}

Writing is a productive skill which is considered as an important element for the students' academic success (Kellogg, 2007). Undoubtedly, the purpose of teaching writing 
skill is to prepare ESL learners to become better writers. Writing is a process and includes the following stages: pre-writing, drafting, editing, revising, and publishing. Pre-writing lays foundation for the writing process and helps the learner to come out of writer's block. It consists of two elements-invention of ideas and arrangement of ideas. Invention of ideas focus on idea generation and revisiting the prior knowledge. Whereas arrangement of ideas focusses on planning and organizing the ideas in a systematic way (Mogahed, 2013).

Researchers have elaborated on the benefits of prewriting. In particular, Poston (2009) claimed that prewriting motivates the learners to come out of writer's block. It is a stage where writers can revisit their prior information and past experiences. Connor and Kramer (1995) believed that prewriting is a helpful technique which guide the writer in constructing one's thoughts in a planned manner which will in the end answer the questions asked.

Very few studies examined the perceptions of learners towards pre-writing stage. Among them the studies of Yunus et al. (2018) and Chien (2010) revealed that students strongly believe in the effective use of pre-writing strategies for the enhancement of writing skills, knowing students' perceptions and beliefs can play a crucial role in developing the right program to meet their needs, and created an awareness of their needs and ESL requirements.

\section{Methodology}

Both qualitative and quantitative methods were used for data collection. A combination of quantitative and qualitative approaches was used in the data analysis and interpretation.

\section{Subjects}

In order to find out students' perceptions of pre-writing strategies, 439 (357 males; 82 - females) undergraduate first year engineering students studying at the Indian Institute of Technology, Bhubaneswar, India were chosen for the study. These students' average age is between 18-20 years and are a mixed group with varied socio-linguistic, education backgrounds across India ranging from intermediate to advanced level proficiency in English language. Although these students represent one particular institution, they come from many states of India.

\section{Tools for Data Collection}

A questionnaire which consisted of 7 statements of students' perceptions on usefulness of pre-writing strategies was designed on the five-point Likert scale ranging from 1-5 options (1. strongly disagree, 2. disagree, 3. neutral, 4. agree, 5. strongly agree). To understand the possible effects of pre-writing strategies, informal interviews with 20 
engineering students were conducted in a random fashion.

\section{Data Collection}

The data was collected by administering the questionnaire online to all the 439 students. Participants were asked to rate their preferences as per the five-point Likert scale ranging from 1-5 options (1. strongly disagree, 2. disagree, 3. neutral, 4. agree, 5. strongly agree). Twenty students were randomly interviewed telephonically, and their responses were recorded.

\section{Statistical Testing}

The data which was collected online through Google form was carefully tabulated into SPSS-26 software for statistical analysis of finding out the reliability of the test components, frequencies, percentages, mean and standard deviations. Also, the independent samples of t-test procedure were formulated. The main aim of this quantitative analysis was to determine if there is any significant difference between the male and female students' perception of the usefulness of pre-writing strategies.

\section{Data Analysis and Interpretation}

The study aimed at understanding the engineering students' perceptions of usefulness of pre-writing strategies. All 439 students were asked to rate the 7 items measuring their perceptions about the pre-writing strategies. The quantitative measures such as reliability analysis of the perceptions of Likert scale, descriptive statistics of the perceptions of pre-writing strategies, descriptive statistics of the seven item Likert scale, and inferential statistics of gender and the perceptions of pre-writing strategies (independent samples t-test (group statistics)) were carried out.

\section{Reliability Analysis}

Table 1 shows the reliability statistics of the variables. The alphas exceeded the minimum value of .70 required for acceptable reliability, especially in the perception scale (Cronbach \& Shapiro, 1982). The scale consists of seven items and the alpha is .804 $(\alpha=.804)$. A measure is moderately reliable if its alpha is .70 or higher (Nunnally \& Bernstein, 1994; cited in JKM Ali, et al, 2019).

Table 1: Reliability analysis of the perception of Likert scale

\begin{tabular}{ccc}
\hline Scale & Number of items & Cronbach's alpha \\
ESL Learners' & 7 & .804 \\
Perceptions of Pre- & & \\
Writing Strategies & & \\
\hline
\end{tabular}


Descriptive statistics of the perceptions of pre-writing strategies.

Table 2: Gender

\begin{tabular}{lccccc}
\hline & & & & & Cumulative \\
& & Frequency & Percent & Valid Percent & Percent \\
\hline \multirow{4}{*}{ Valid } & Male & 356 & 81.1 & 81.3 & 81.3 \\
& Female & 82 & 18.7 & 18.7 & 100.0 \\
& Total & 438 & 99.8 & 100.0 & \\
\multirow{2}{*}{ Missing } & System & 1 & .2 & & \\
& Total & 439 & 100.0 & & \\
\hline
\end{tabular}

According to the figures in the table, the majority, $81.1 \%$ of the respondents are male students which is 356 out of 438 . The rest of the $18.7 \%$ are female students which is 82 out of 438 .

Table 3: Descriptive statistics of the seven item likert scale

\begin{tabular}{lcccc} 
& $\mathrm{N}$ & Sum & Mean & Std. Deviation \\
\hline $\begin{array}{c}\text { 1.Pre-writing must be done } \\
\text { before the actual writing } \\
\text { begins. }\end{array}$ & 436 & 1742 & 4.00 & .850 \\
$\begin{array}{c}\text { 2. Pre-writing helps in } \\
\text { discovering initial ideas } \\
\text { about a topic. }\end{array}$ & 436 & 1863 & 4.27 & .722 \\
$\begin{array}{c}\text { 3. Pre-writing involves } \\
\text { thinking and planning about } \\
\text { the topic. }\end{array}$ & 436 & 1881 & 4.31 & .705 \\
$\begin{array}{c}\text { 4. Pre-writing strategies } \\
\text { improve academic writing. }\end{array}$ & 436 & 1764 & 4.05 & .810 \\
$\begin{array}{c}\text { 5. Pre-writing techniques } \\
\text { motivate me to plan my } \\
\text { writing very well. }\end{array}$ & 436 & 1790 & 4.11 & .790 \\
$\begin{array}{c}\text { 6. The hardest part of writing } \\
\text { is getting started to writing } \\
\text { itself. }\end{array}$ & 436 & 1727 & 3.96 & .913 \\
$\begin{array}{l}\text { 7. Planning increases } \\
\text { coherence in the pre-writing } \\
\text { stage. }\end{array}$ & 436 & 1831 & 4.20 & .691 \\
$\quad$ Valid N (listwise) & 436 & & & \\
\hline
\end{tabular}


According to Pimentel (2010), the five-point Likert scale is considered an interval scale. The mean is very significant. From 1 to 1.8 , it means strongly disagree. From 1.81 to 2.60 , it means disagree. From 2.61 to 3.40 , it means neutral; from 3.41 to 4.20 , it means agree; from 4.21 to 5 , it means strongly agree.

The items can be ranked from the most agreed with to the least agreed, based on the mean. The first statement the majority of students agree is that pre-writing involves thinking and planning about the topic $(\mathrm{M}=4.31, \mathrm{SD}=0.705)$. The second statement is that pre-writing helps in discovering initial ideas about a topic, $(\mathrm{M}=4.27, \mathrm{SD}=0.722)$. The third statement is that planning increases coherence in the pre-writing stage $(\mathrm{M}=4.20, \mathrm{SD}=0.69)$. The fourth statement is that pre-writing techniques motivate me to plan my writing very well $(\mathrm{M}=4.11, \mathrm{SD}=0.79)$. The fifth statement is that pre-writing strategies improve academic writing $(\mathrm{M}=4.05, \mathrm{SD}=0.85)$. The sixth-ranked statement is that pre-writing must be done before the actual writing begins $(\mathrm{M}=4.00, \mathrm{SD}=0.85)$. The last ranked statement is that the hardest part of writing is getting started to writing itself $(\mathrm{M}=3.96, \mathrm{SD}=0.91)$.

Inferential statistics of gender and the perceptions of pre-writing strategies.

Table 4: Independent samples t-test (Group Statistics)

\begin{tabular}{cccccc} 
& Gender & $\mathrm{N}$ & Mean & Std. Deviation & Std. Error Mean \\
\hline Perceptions of & Male & 354 & 4.1130 & .55524 & .02951 \\
Pre-Writing & Female & 82 & 4.1916 & .42009 & .04639 \\
Strategies & & & & & \\
\hline
\end{tabular}

The independent samples t-test reveals that there is no statistically significant difference in the mean scores of male and female students concerning the perceptions of pre-writing strategies $\mathrm{t}(1.205)=434, \mathrm{p}=.229)$. Worth noting is that the non-parametric Mann-Whitney U-Test also shows that there is no statistically significant difference between male and female students about their perceptions towards prewriting strategies.

\section{Discussion}

From the analysis and description of the data, we can interpret the engineering students' perceptions of usefulness of pre-writing strategies as follows. First, it is interesting to know that majority of the students are of the opinion that pre-writing involves higher order skills such as thinking, planning about the topic. Second, students also seem to believe that pre-writing strategies help in discovering initial ideas about a topic. In other words, students seem to strongly support the idea that using pre-writing strategies such as brainstorming and mind mapping help them gather more ideas required to explain the topic. Third, students seem to believe that planning as a pre-writing strategy can help them achieve coherence in overall writing. Forth, students think that motivation to plan one's 
writing is very much possible when one adheres to pre-writing strategies. Next, most importantly, students feel that careful application of pre-writing strategies lead to their academic success. It means that students are aware that much of their academic communication involves writing for activities such as: writing assignments, doing electronic communication, writing project proposals and then projects, filling in applications for jobs and applying for higher education purposes and preparing their own resumes and curriculum vitae for applying for jobs. Then, students are also of the opinion that pre-writing activity precedes the actual writing stage. We can assume that students who are aware of this process will do well in their writing activities or tasks. Finally, students rightly acknowledge that hardest part of writing is getting started to writing itself. It can be concluded that engineering students, giving more importance to core subjects, generally have a tendency to ignore and give less importance to writing.

The independent samples of t-test results (table 4) show that there is no statistically significant difference in the mean scores of male and female students concerning the perceptions of pre-writing strategies. It implies that in the ESL context, in India, generally most of the engineering students at premiere institutions having come from good education background are aware of the importance of English language for their academic success. Hence, all students irrespective of gender seem to have positive perception of usefulness of pre-writing strategies in improving their writing.

Most of the engineering students agreed with the question, does self-assessment have any impact in improving your writing skills? It means that these students seem to understand that writing is a process and are aware of the benefits of self-assessment of their improvement in writing. Three out of 20 students were unsure of the positive effects of self-assessment of writing. It was because these three students lacked the awareness of the importance of self-awareness in improving skills.

Continuous self-assessment of skills and learning can be seen as an important trait of advanced students. It is because self-assessment is an ability to identify one's strengths and weaknesses in learning which drives students to improve their academic performance. Additionally, self-assessment benefits students as it prompts them to higher order language skills such as: thinking, brainstorming for ideas, evaluating and revising their own writing. Most importantly, as writing is a process, self-assessment helps students to be aware of the other processes involved in learning and improving writing. Thus, self-assessment not only makes students independent and responsible for their own improvement in writing, but also motivates them to learn other language skills which are closely associate with writing.

\section{Conclusion}

The study offers some important insights for improving pre-writing at various levels of teaching and learning. First, to help engineering students improve their writing, a thoughtful and comprehensive curriculum which focuses on imparting skills especially 
writing is the need of the hour. Such curriculum will help students perform better in their career by bringing together all knowledge of language skills learned during the study programme.

Teachers may be aware that engineering students employ various learning styles based on the education backgrounds they come from. Therefore, it is important that the language teachers diagnose these students' writing issues and other skills closely related to improving writing. Accordingly, it is recommended that the teachers may design and administer writing tasks with reference to technical topics as engineering students may find them familiar and easy.

Teachers may focus on evaluating students' written assignments and lab reports and may give constructive feedback to students for improving their writing. Further, teachers may also encourage pair work and group assignments to students so that there is more scope for students to learn from each other.

Students may put into practice their understanding and positive perceptions about the usefulness of pre-writing strategies. Students may make use of all the resources and help available and provided such as library facilities, and remedial classes. Students may also actively participate in other extracurricular activities such as essay writing, poetry writing by the institute, college or university.

Writing skills are important and majorly contribute to engineering students' academic success and professional career. Writing is a process from pre-writing stage through the writing stage to post writing stage. This present study aimed at understanding the engineering students' perceptions of usefulness of pre-writing strategies. Pre-writing demands students' knowledge of higher order skills such as critical thinking, brainstorming, planning, evaluating, organizing, editing and proofreading. However, engineering students may relegate the importance of writing if they lack knowledge of selfassessment of writing through reflection and practice. Most importantly, students should focus on pre-writing strategies which would motivate and scaffold their actual writing.

Finally, this study has provided an important opportunity to the researchers to advance the understanding of self-reflection of their teaching practices especially with the writing skill. The limitation of the study is that it focused only on the engineering students' perceptions of usefulness of pre-writing strategies. The researchers feel that further research may be carried out in assessing engineering students' awareness of idea generation and organization strategies of pre-writing.

\section{References}

Bailey, K. M. (1998). Learning about language assessment. Cambridge, Heinle \& Heinle.

Boud, D. (1995). Enhancing learning through self-assessment. London: Kogan Page.

Boud, D. J., \& Falchikov, N. (1989). Quantitative studies of student self-assessment in 
higher education: A critical analysis of findings. Higher Education, 18, 529-549.

Bjork, R. A. (1994). Memory and metamemory considerations in the training of human beings. In J. MetĞ calfe \& A. E Shimamura (Eds.), Metacognition: Knowing about knowing. 185-205. Cambridge, MA: MIT Press.

Bjork, R. A. (1999). Assessing our own competence: Heuristics and illusions. In D. Gopher \& Koriat (Eds.), Attention and performance XVII. Cognitive regulation of performance: Interaction of theory and application. 435-459. Cambridge, MA: MIT Press.

Broad, J. (2006). Interpretations of independent learning in further education. Journal of Further and Higher Education, 30(2), 119-143.

Brown, G. T., \& Harris, L. R. (2013). "Student self-assessment," in Sage Handbook of Research on Classroom Assessment, ed J. H. McMillan (Los Angeles, CA: Sage), 367-393. https://doi.org/10.4135/9781452218649.n21

Cronbach, L. J., \& Shapiro, K. (1982). Designing evaluations of educational and social programs. San Francisco: Jossey-Bass.

Hargreaves, A., Earl, L., \& Schimidt, M. (2001). Perspectives on alternative assessment reform. American Educational Research Journal, 39(1), 69-95.

Hughes, K., \& Mylonas, A. (2002). Developing procedures for implementing peer assessment. Assessment \& Evaluation in Higher Education, 27(5), 427-441. https://doi.org/10.1080/0260293022000009302

JKM Ali., Shamsan, M.A., Guduru, R., \& Yemmela, N. (2019). Attitudes of Saudi EFL Learners towards Speaking Skills. Arab World English Journal, 10(2), 253-364. https://dx.doi.org/10.24093/awej/vol10no2.27

Kellogg, R. T., \& Raulerson, B. A. (2007). Improving the writing skills of college students. Psychonomic Bulletin and Review, 14(2), 237-242. https://doi.org/10.3758/BF03194058

Marhaeni, A.A.I.N., \& Artini, L.P. (2015). Asesmen autentik dan pendidikan bermakna: Implementasi Kurikulum 2013. Jurnal Pendidikan Indonesia, 4(1), 499-511.

Mogahed, M. M. (2013). Planning out Pre-Writing Activities. International Journal of English and Literature, 4(3), 60-68. http://www.academicjournals.org/IJEL

Nedzinskaite, I., Švenčionienè, D., \& Zavistanavičienė, D. (2006). Achievements in language learning through students' self-assessment. Studies about Languages, 8(1), 84-87.

Panadero, E., Brown, G. L., \& Strijbos, J. W. (2016). The future of student selfassessment: a review of known unknowns and potential directions. Educational Psychology Review, 28, 803-830. https://doi.org/10.1007/s10648-015-9350-2

Pimentel, J. (2010). A note on the usage of Likert scaling for research data analysis. USM R \& D Jounal, 18(2), 109-112.

Ross, J. A., Rolheiser, C., \& Hogaboam-Gray, A. (1999). Effects of self-evaluation training on narrative writing. Assessing Writing, 6(1), 107-132.

Shie Chieh - Chien. (2010). Enhancing English Composition Teachers Awareness of Their Students Writing Strategy Use. The Asia-Pacific Education Researcher, 19(3), 417-438.

Thongpai, J., \& Deerajviset, P. (2017). Effects of self-assessment on writing of Thai 
EFL students in different groups of learning styles. In ASEAN/Asian Academic Society International Conference Proceeding Series.

Yunus, M. M., Hashim, H., Sulaiman, N. A., Sulaiman, W. S. M., Richmond, R. L., Jarail, S., \& Royal, N. (2018). Students' Awareness and Perceptions towards "PreWriting Stage" as a Strategy in Writing Directed Essay. Creative Education, 09(14), 2215-2223. https://doi.org/10.4236/ce.2018.914162

Zahra Fahimi \& Ali Rahimi (2015). On the Impact of Self-Assessment Practice on Writing Skill. Journal: Procedia - Social and Behavioral Sciences, 192, 730736. https://doi.org/10.1016/j.sbspro.2015.06.082 


\section{Appendix}

Table 5: Independent Samples Test of Gender and Perceptions

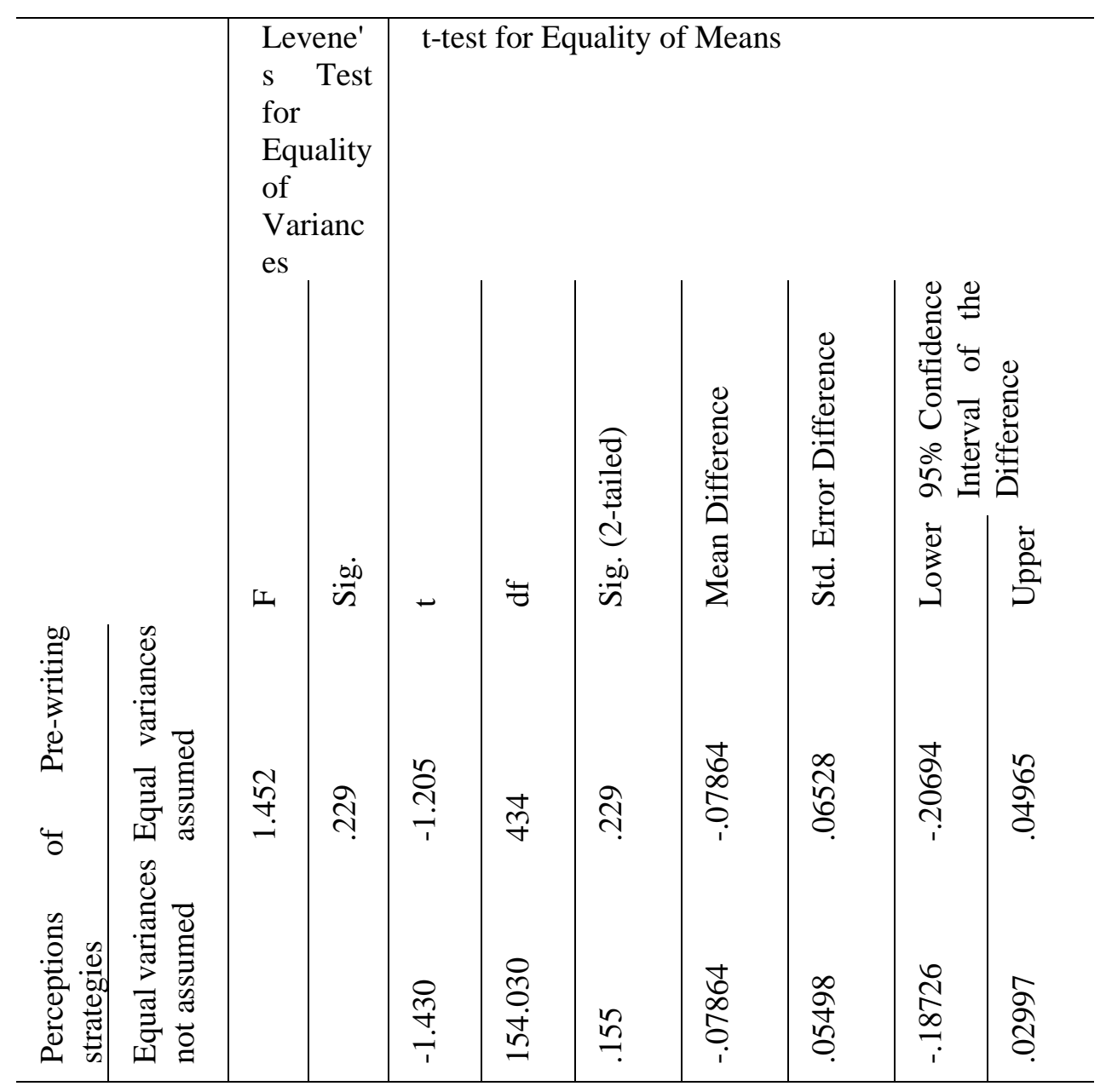


Table 6: Independent-Samples Mann-Whitney U Test Summary

\begin{tabular}{ll}
\hline Total N & 436 \\
Mann-Whitney U & 15436.000 \\
Wilcoxon W & 18839.000 \\
Test Statistic & 15436.000 \\
Standard Error & 1023.249 \\
$\begin{array}{l}\text { Standardized Test Statistic } \\
\begin{array}{l}\text { Asymptotic Sig.(2-sided } \\
\text { test) }\end{array}\end{array}$ & .901 \\
\hline
\end{tabular}

